\title{
実船を用いた船体応答計測について
}

\author{
武田 誠一*・佐藤 要*・井上 清*
}

\section{A Study on Hull Response by Field Measurement}

Seiichi TAKEDA, Kaname SATOH and Kiyoshi INOUE

\begin{abstract}
It is important to confirm the hull response of a fishing boat in operation for checking the safety sea-keeping qualities and automation of fishing. For this purpose, a hull response system was developed and installed on the training ship Shinyo-maru (Tokyo University of Fisheries).

Before a long time testing on board, we had a performance test for the system when the ship was on the still water. We measured and analyzed specially on the longitudinal bending stress. It was confirmed that the experimental values acting on the midship agree with the calculated one.

Also the hull response while cruising was analyzed utilizing on board test of the system. Using wave direction as a parameter, a high correlation between the wa ve height and the hull responses, as well as among each of hull responses was obtained. This suggests that one of the hull responses could be estimated using the value of other hull response.
\end{abstract}

\section{1. 緒言}

実際に運航している船舶の船体運動, 応力, 加速度等に関する船体応答を直接計測し, その状態を操船者に提 供し操船上の判断に役立てることを目的としたシステムが大型貨物船等を対象として開発され(1 4), 理論值との 比較やシステムの必要性についても検討がなされている(5 10)。一方，漁船は一般商船と異なる運航条件，即ち 各種漁具・漁業機器を船上に配置し，操業を行ならといら付加的条件が課せられており，またとの船体形状も大 きく相違する。このことは漁船の船体運動特性に強い影響を及ぼすものと考兄られ, 海洋波中の船体運動の実船 計測およびそれらのデータ解析結果についての報告もなされている(11 14)。

筆者らは, 漁船においてもその船体応答諸量を直接計測するシステムが必要であると考光, 漁船のための船体 応答解析システムを東京水産大学練習船神鷹丸に設置し，長期の計測を開始している ${ }^{(15)}$ 。船体応答諸量のうち， 船体構造の基礎とるなる船体縱灾力について，供試船の入渠期間に静水中と乾船渠着床中について縱応力の変化 状態等を計測するとともに(16)，航行中の船体灾答について実船計測実験を実施し(17)，応力，加速度等の頻度分 布, ならびに各船体応答と波高, および波の出会い角度との相関について解析し, 若干の知見を得たのでここに 報告する。

\section{2. 実船実験の概要}

\section{1 供試船和よび計測装置}

供試船は東京水産大学練習船神䳡丸で, 船尾トロール型の船型である。その主要目を表 1 亿示す。神䳭丸に設 置した船体応答解析システムは，多岐にわたる監視項目の計測データをテレビモニタを通じて操船者に提供し， 同時にデータの記録及び解析を行ならことができるものである。機器の構成, ならびに各種センサの配置につい

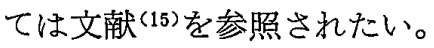

* 正会員 東京水産大学（于105 東京都港区港南 4-5-7） 
表 1 神鷕丸の主要目

\begin{tabular}{lc}
\hline \hline Iteal & Remark \\
\hline Gross tonnage & $649.0 \mathrm{tons}$ \\
Length between perpendiculars & $53.000 \mathrm{~m}$ \\
Breadth molded & $10.600 \mathrm{~m}$ \\
Depth molded & $6.800 \mathrm{~m}$ \\
Maine engine & 4 cycle medium speed diesel \\
& $1.580 \mathrm{~kW}$ \\
& output \\
revolution & $900 \mathrm{rpm}$ \\
\hline
\end{tabular}

2.2 実駼方法

\section{2 .1 静水状態}

本実験では，各種センサのうち応力計，加速度 計，傾斜計の作動状況，基準点の確認等を静水状 態で実施するとともに，監視項目の基本となる縦 曲げ応力を応力計（歪ゲージ）により計測を行な った。船楼甲板の縦曲げ応力の計測は1987年12月

に神鷹丸が乾船渠に入渠した際に行なわれた。船体応力の計測基集については，入渠時，船渠門を閉鎖し水面が 静穏となった静水状態で各機器を調整し零点を求め, この時の船体状態を基準とした。加速度, 船体傾斜につい ては，船体が盘木に着床し支柱により完全に垂直状態に保たれた時期に，その基準を定めた。

乾燥渠入渠中は全ての清水槽及び脚荷水槽を空にしているが，入出渠時の各水槽への清水積込量は同量となる 様に配慮している。

\subsection{2 航行状態}

実験は波高叔よび波の出会い角度と船体応答との関係を明らかにすることを目的とした。波の出会い角度が右 廻りで $0 ， 45 ， 90 ， 135 ， 180 ， 225 ， 270 ， 315$ 度となるように神鷹丸を航走させ，各センサからのデータを，サ ンプリング間隔 0.5 秒で10分間の計測を常態としている。プロペラ翼角は 17.0 度で一定とした。然料ハンドル位 置も同様に一定である。

表 2 実験時の最大波高および有義波高 $(\mathrm{m})$

\begin{tabular}{cccc}
\hline \hline Test No. & Date & Maximum & Significant \\
\hline 1 & Jul. 21,1988 & 1.22 & 0.83 \\
2 & Jul. 27,1988 & 1.74 & 1.13 \\
3 & Aug. 4, 1988 & 2.45 & 1.45 \\
4 & Aug. 23, 1988 & 1.13 & 0.72 \\
5 & Jan. 30,1989 & 4.72 & 3.24 \\
6 & Jan. 31,1989 & 1.90 & 1.26 \\
\hline
\end{tabular}

実験は，1988年 7 月 21 日に第 1 回目を実施し， 1990年 1 月31日迄, 計 6 回行なった。表 2 亿各実 験時の最大波高と有義波高を示す。最大波高は 1. 13 4.72m，有義波高で $0.72 \sim 3.24 \mathrm{~m}$ と，平 穏な海況から荒天の海況までの広範囲にわたって 実験が実施された。なお，5回目の実験では，計 測中に船体横傾斜が大きくなったため，途中で実

験を中止した。したがって，計測は波の出会い角で180度から 0 度迄（右廻り）の 5 点方位となった。

\section{3. 結果および考察}

\section{1 静水状態}

入渠時の船体が盤木に着床する迄の応力变化を図 1 に，出渠時の船体が浮上する迄の応力变化を図 2 に示して いる。両図とも縦軸に応力值を，横軸に時間をとっておう，実線は船首部綎曲げ応力を，一点鎖線は中央部縦曲 ゲ応力を，二点鎖線は船尾部縦曲げ応力をそれぞれ示している。応力值の符号は，甲板が引っ張り，即ち船底面 が圧縮となる縦曲げ応力を正とした。

図 1 の船体着床初期, 即ち入渠時に执いて船体船首部の竜骨が艋木に接触した（45分後）頃，拉よび図 2 の船 体浮上初期, 即ち出渠時の船体船首部の竜骨が盤木から離れた（約 30 分後）頃に，船体中央部に $+0.4 \mathrm{~kg} / \mathrm{mm}^{2} の$ 曲げ応力が作用しているのが認められる。これは船体中央部に集中する浮力によるるのと考兄られる。入渠時船 渠門を閉鎖しまだ船体が浮上している状態を基準とするため，このときの各部の応力值が零となるように各機器 を調整したが，表 3 に示すように，船尾部に関しては+0.1 $\mathrm{kg} / \mathrm{mm}^{2}$ の応力値が初期状態として残っている。

入渠時, 乾船渠内の海水の排出が完了し，船体が盤木に完全に着床した状態での各部の応力值は，船首部で, $-0.2 \mathrm{~kg} / \mathrm{mm}^{2}$ ，中央部でー $1.3 \mathrm{~kg} / \mathrm{mm}^{2}$ ，船尾部で+0.6 $\mathrm{kg} / \mathrm{mm}^{2}$ であった。このことより船体が浮上している時との応 力差は，船首部で $-0.2 \mathrm{~kg} / \mathrm{mm}^{2}$ ，中央部でー $1.3 \mathrm{~kg} / \mathrm{mm}^{2}$ ，船尾部で $0.5 \mathrm{~km} / \mathrm{mm}^{2}$ となる。したがって，船体が盤木 に着休している状態を基準にして船体が浮上している状態を考えると，船体が浮上している状態では船首部，中 央部には甲板に引っ張りの力が作用しているのに対し，船尾部には圧縮の力が作用していることがわかる。

出渠時乾船渠内へ海水注水を開始する前の船体が盤木に着床している状態での各部の応力值は, 船首部でー0.9 $\mathrm{kg} / \mathrm{mm}^{2}$ ，中央部でー $1.3 \mathrm{~kg} / \mathrm{mm}^{2}$ ，船尾部で $+0.5 \mathrm{~kg} / \mathrm{mm}^{2}$ を示し，入渠時に盤木に着床している状熊と比較すると， 中央部と船尾部ではほとんど差が認められないのに対し，船首部では $-0.7 \mathrm{~kg} / \mathrm{mm}^{2}$ の差が生じている。この原因 
は後述するように，気温の影響によるものと考光られる。

乾船渠内への海水注水が完了し船体が浮上した時の各部の応力值は，船首部でー $0.3 \mathrm{~kg} / \mathrm{mm}^{2}$, 中央部で一0. $1 \mathrm{~kg}$ $/ \mathrm{mm}^{2}$, 船尾部で $0.0 \mathrm{~kg} / \mathrm{mm}^{2}$ であった。この時の船体が浮上している状態と, 船体が盤木に着床している状態と の応力差は, 船首部で $-0.6 \mathrm{~kg} / \mathrm{mm}^{2}$, 中央部で $-1.2 \mathrm{~kg} / \mathrm{mm}^{2}$, 船尾部 $+0.5 \mathrm{~kg} / \mathrm{mm}^{2}$ となる。これる渠時と比較 すると，船体中央部と船尾部ではほぼ同じ值となっているのに対し，船首部では $+0.4 \mathrm{~kg} / \mathrm{mm}^{2}$ の差がみられた。

な执入渠時船体船尾部が盤木に乗ってから排水完了迄に要した時間は約 4 時間であり，出渠時注水から船体浮 上までに要した時間は約40分である。

乾船渠入渠中の船体各部の応力と, 気温の日変化を図 3 に示す。縦軸に気温和よび応力值を, 横軸には時間を とっている。○印を連ねた実線は気温を，○， $\mathbf{\Delta} 、 \Delta$ 印を連ねた笑線はそれぞれ船首部，中央部，船尾部の各船 体縦曲げ応力を示している。船体各部の応力は一定していない。これは入渠中も船体諸工事のため，機械等の積 み降ろしが日中行なわれているためである。この重量変化が応力值に影響を与えているものと思われるが，船体 中央部及び船尾部の応力変化に比較して, 船首部の応力変化と気温の日変化に強い相関が認められる。船体中央

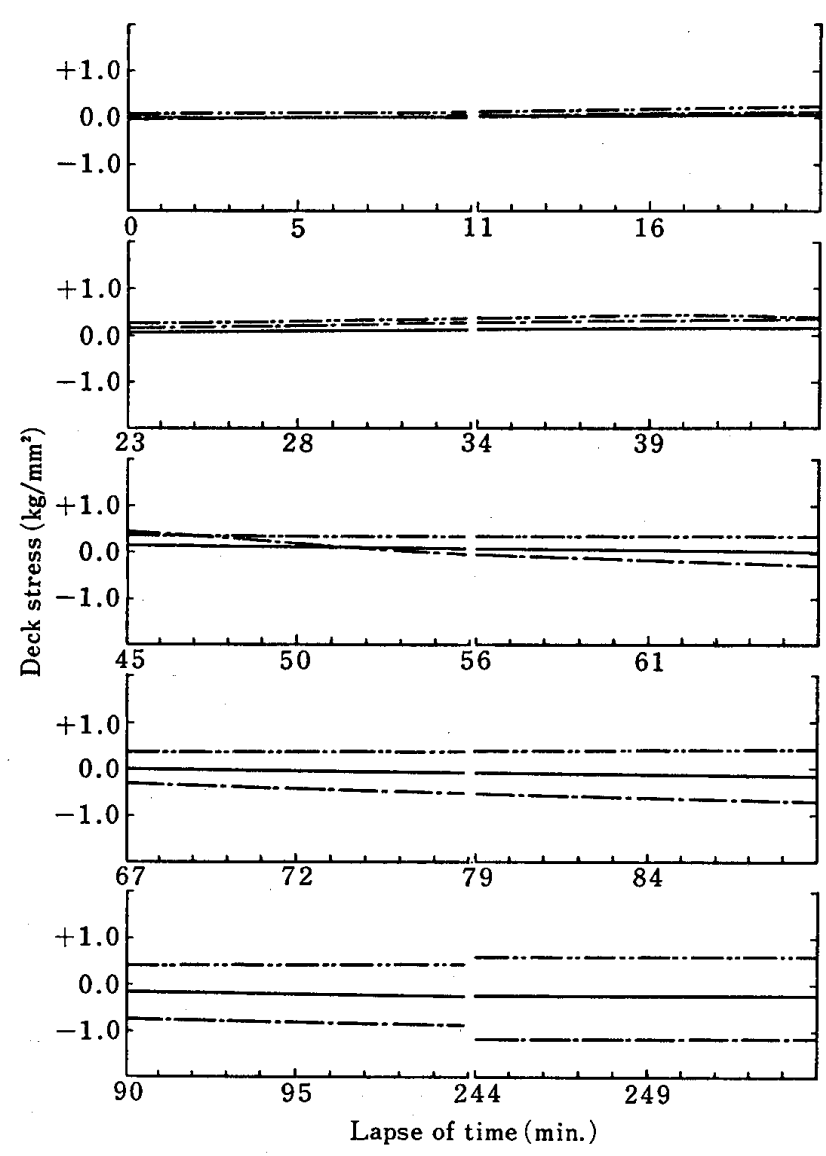

図 1 入渠時の甲板縦曲げ応力の変化

$\begin{array}{ll}- & \text { ： 船 首 部 } \\ \cdots & \text { ： 中 央 部 } \\ \cdots \cdots . . . . . . & \text { : 船 尾 部 }\end{array}$

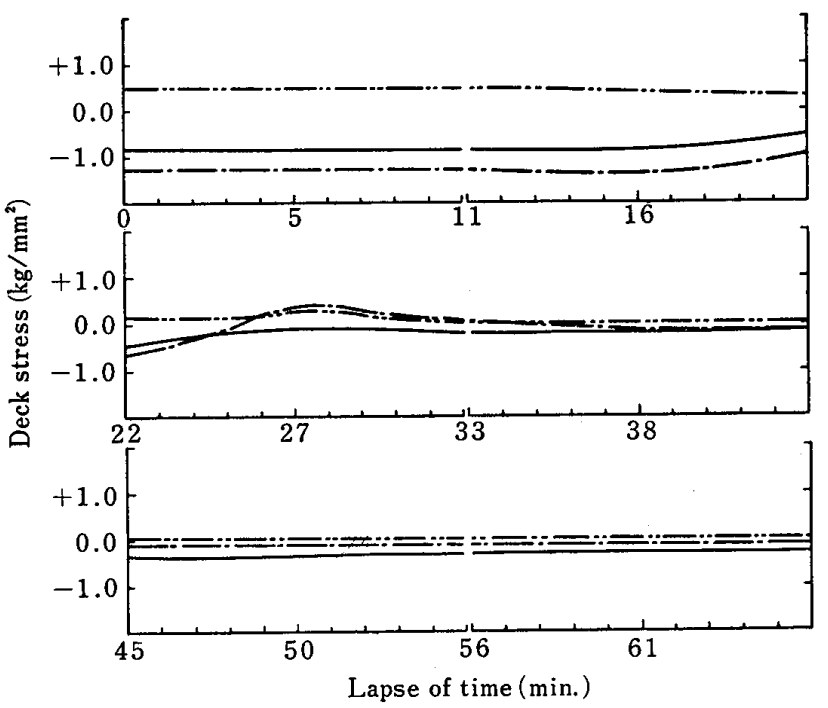

図 2 出渠時の甲板縦曲げ応力の変化

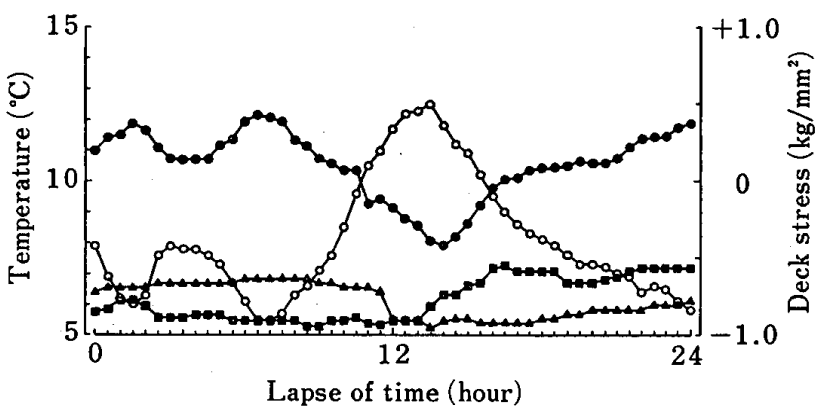

図 3 気温と甲板縦曲げ応力の日変化

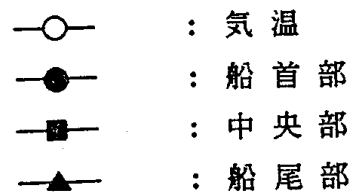


表 3 入出渠時の船体縦曲げ応力 $\left(\mathrm{kg} / \mathrm{mm}^{2}\right)$

\begin{tabular}{llccc}
\hline & & bow-ward & midship & sternward \\
\hline Docking floated & 0.0 & 0.0 & +0.1 \\
Undocking on the keelblocks & -0.2 & -1.3 & +0.6 \\
& on the keelblocks & -0.9 & -1.3 & +0.5 \\
& floated & -0.3 & -0.1 & 0.0 \\
\hline
\end{tabular}

れなかった。

建造時に，詳細な積み上げ計算によって作成された神鷹丸の船体重量分布特よび浮力分布の資料(18)より，入 渠時および出渠時の船体状態に拈ける剪断力曲線と, 縦曲げモーメント曲線を求め, 図 4 (a)〜(b)に示す。縦軸に 剪断力と縦曲げモーメントをとり，横軸に船の長さを船首垂線(F．P.)を右側に，船尾垂線(A．P.)を左側にと っている。船体中央より左側の部分（後部）が右側の部分（前部）を下方に剪断する場合の剪断力を正，また甲 板が引っ張り，即ち船底面が圧縮となる縦曲げモーメントを正とした。図 4 (a)〜(b)に示されているように，計算 によれば入出渠状態の船体には，船首尾にわたって甲板が引っ張り，船底面が圧縮となる縌曲げモーメントが動 き，いわゆるホギング状態となっているのがわかる。

入出渠時, 縦曲げ応力計を設置している箇所 (中央部) に括ける縦曲げモーメントは, 図 $4(\mathrm{a})$ (b)の縦曲げモ ーメント曲線より，入渠時 $876.96 \mathrm{t}-\mathrm{m}$, 出渠時 $886.64 \mathrm{t}-\mathrm{m}$ を得る。

船体の曲げ応力 $\sigma$ は，曲げモーメントが最大となる中央部付近で，断面係数（断面抵抗率）が最も小さい断 面 (強度断面) に执いて次式によって計算される。

$$
\sigma=\frac{1000 \times M}{Z} \quad\left[\mathrm{~kg} / \mathrm{mm}^{2}\right]
$$

$M:$ 静水中縦曲げモーメント $[\mathrm{t}-\mathrm{m}]$

$Z$ : 断面係数 $\left[\mathrm{mm}^{2} \times \mathrm{m}\right]$

神鷹丸の断面係数は， $667,080 \mathrm{~mm}^{2} \times \mathrm{m}$ と計算されて和り (19)，船体中央部での縦曲げ応力 $\sigma$ は，(1)式より $\sigma$ (入渠時 $)=1.31 \mathrm{~kg} / \mathrm{mm}^{2}$

$\sigma($ 出渠時 $)=1.32 \mathrm{~kg} / \mathrm{mm}^{2}$

となる。

入出渠時に於ける計測では，表 3 に示したように船体浮上時と船体着床時との応力差はいずれも $1.3 \mathrm{~kg} / \mathrm{mm}{ }^{2}$ であり，前記の計算值とよく一致している。またこの值は神鸜丸の許容縦曲げ応力値の $1 / 9$ にあた大きさであ る(16)。

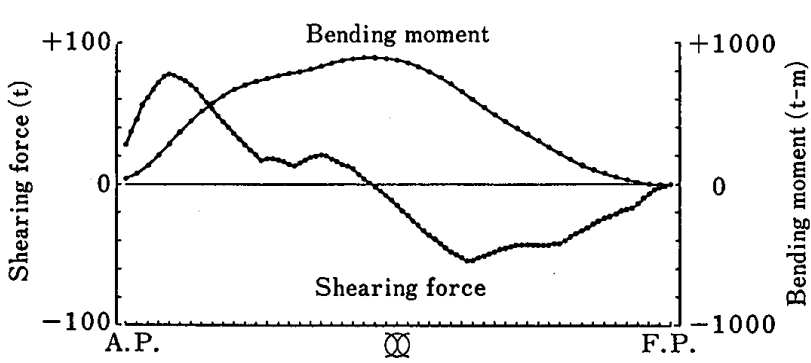

(a) 入渠時

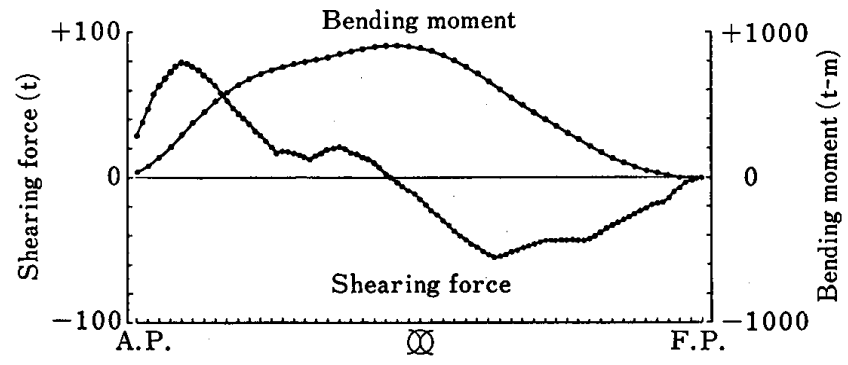

(b) 出渠時

図 4 剪断力曲線扣よび縱曲げ応力曲線

\section{1 航行中}

船体応答解析システムにより得られたデータを用いて，前述の各文献(1 4)で船体応答の変動の指標として用い られている累積エネルギー密度の平方根 $\sqrt{E}$ を求めた。

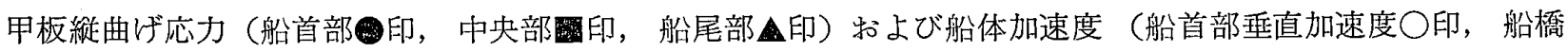
水平加速度 $\square$ 印）について、 $\bar{E}$ の分布を図 5 , 図 6 に示す。緃曲げ応力の作用は船尾部で最も小さく，次いで船 


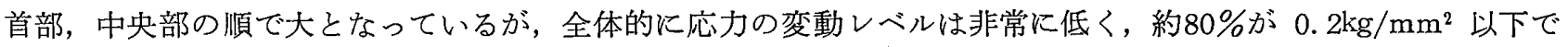
あった。長期間の実測が行なわれている自動車運搬船や大型ばら積貨物船の例 (2,3) と比較しても神鷹丸の応答レ ベルは低い。V $\bar{E}$ の最大值は，有義波高で $3.24 \mathrm{~m}$ の波を船首右45度に受けて航走している時に計測された。その 值は0. $43 \mathrm{~kg} / \mathrm{mm}^{2}$ である。このときの変動のピーク值は+1.38〜+2.92 $\mathrm{kg} / \mathrm{mm}^{2}$ であり，甲板縦曲げ応力はホギン グ状態の範囲内での変動となっている。前述の船舶の例では，その変動值がサギング状態側にまで及んでいる点 に相違がある。これは神鷹丸の船体横断面の断面係数が，建造時の計算值で $667,080 \mathrm{~mm}^{2} \times \mathrm{m}$ と，船体縱強度に 十分余裕があること，执よび船体長さと波長の関係により，神鷹丸の場合では応力の值がホギング状態の範囲の 中だけで変動したものと考えられる。

船首部垂直加速度のV $\bar{E}$ の最大值は0.164 gであり，有義汥高で $3.24 \mathrm{~m}$ の波を船首方向より受けて航走してい る時に計測された。その時の変動のピーク值は+0.303（十記号は上向き）〜一 $0.376 g$ (一記号は下向き）であ った。また船橋の水平加速度の $\sqrt{E}$ の最大值は有義波高で $3.24 \mathrm{~m}$ の波を右舷正横より受けて航走している時に計 測され，0.164gであった。変動のピーク值は十0.158(十記号は右向き)〜一 $0.254 \mathrm{~g}$ (一記号は左向き)である。 この海況で左舷正横より波を受けて航走した時の水平加速度の計測は，前述したように船体横傾斜が大となった ために，実施されていない。前述の自動車運搬船および大型ばら積貨物船と神鷹丸との比較では，その相違は特 に認められなかった。

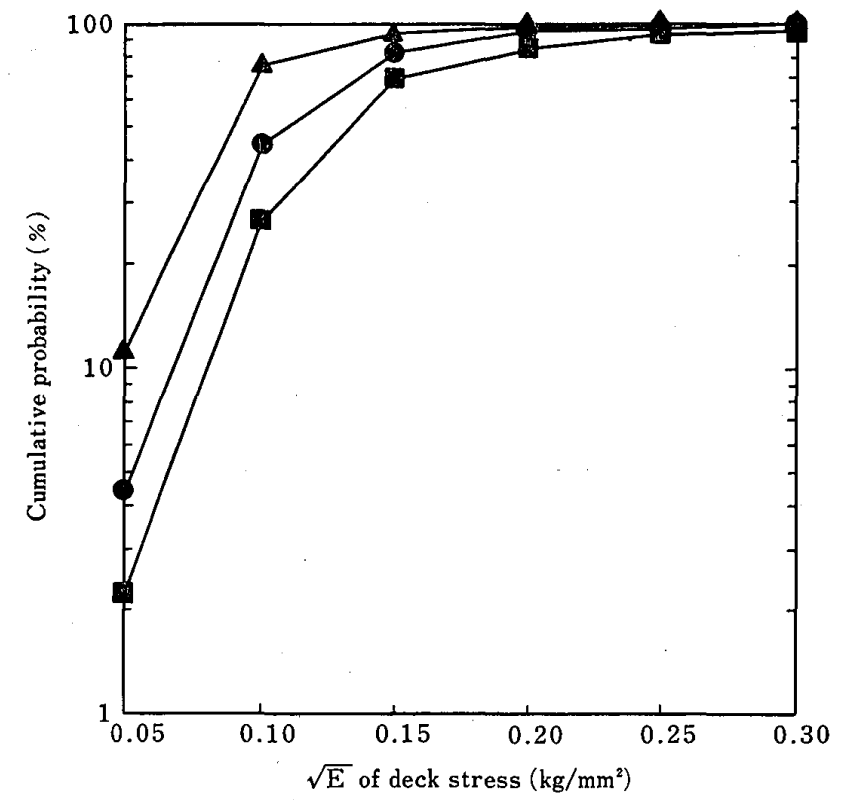

㘠 5 甲板縦曲げ応力の $V \bar{E}$ の分布

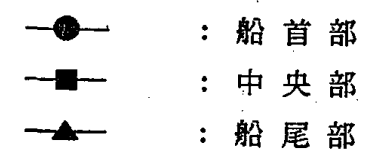

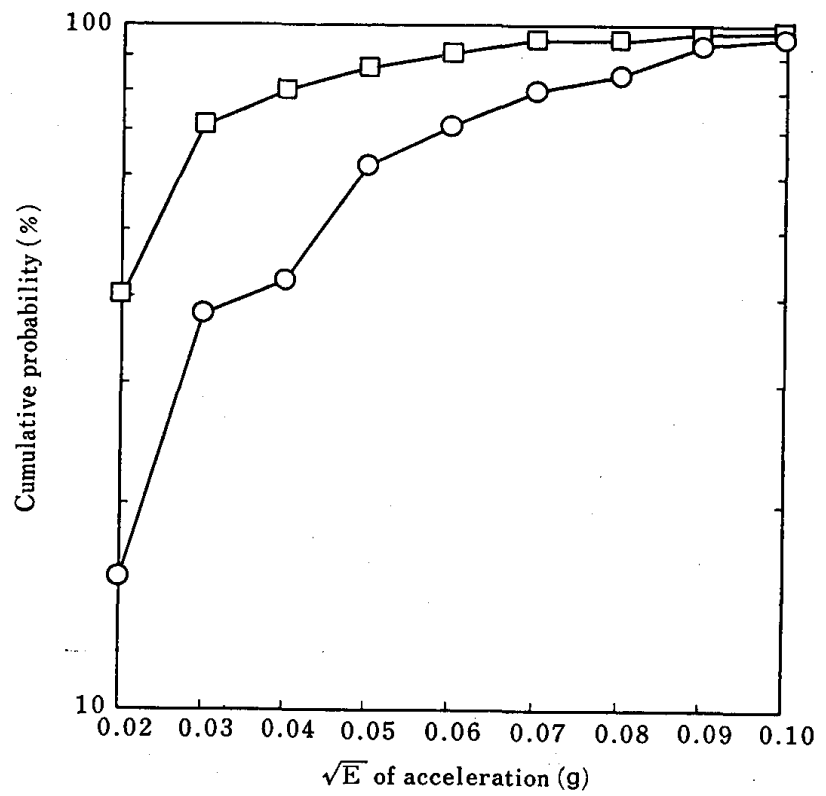

図 6 加速度の $\sqrt{E}$ の分布

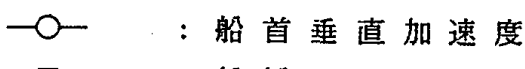

：船橋水平加速度

図 7 (a) (e)は波高・波の出会い角度と，船体応答との関係について示したものである。各図とも縱軸に応答の

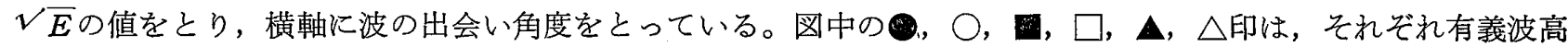
$0.72,0.83,1.13,1.26,1.45,3.24 \mathrm{~m}$ の海沅時の値を示す。

図 7 (a) (c)に船首部，中央部，和よび船尾部の船体縦曲げ応力の解析結果を示す。これによれば，応力変動が 小さくなるのは左䑨正横に波を受けて航走している状態である。しかしながら，応力変動が大きくなる状態は船 体各部で若干の相違が認められる。即ち, 中央部では波の出会い角度で225度(右斜め後方から波を受ける状態), 船尾部では315度（右斜め前方から波を受ける状態）で応力変動が大きくなるのに対し，船首部では 225 度〜315 度の範囲でその変動が大きくなっている。ぬた，相対的に左舷側に波を受けて航走している状態よりも，右艆側 に波を受けて航走している状態がその㐫力変動は大きいものとなっている。これは応力センサが左舷側にのみ設 


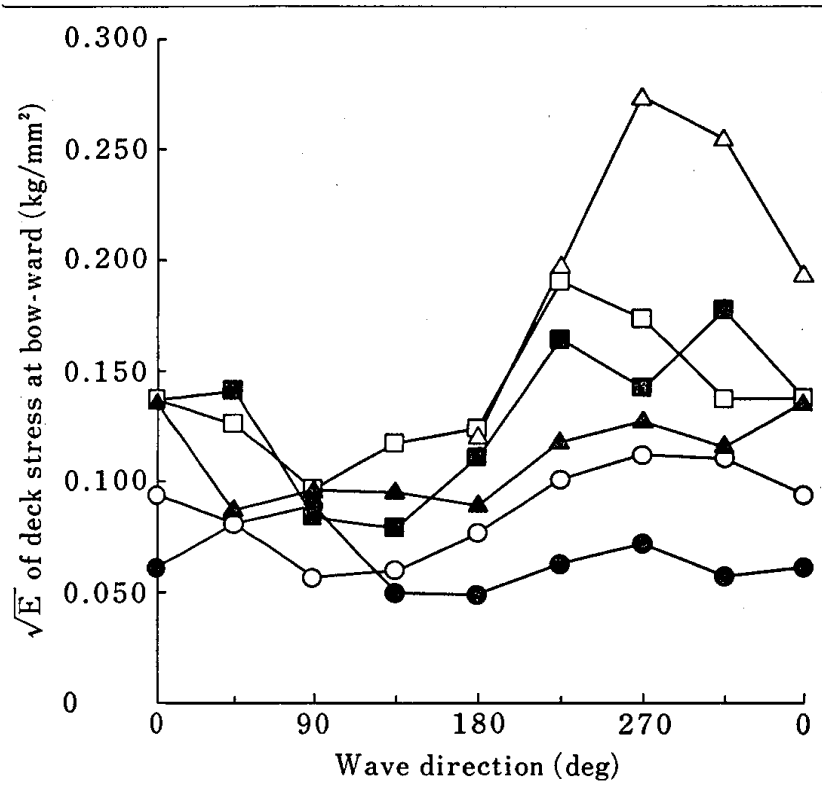

(a) 船首部甲板緃曲げ応力

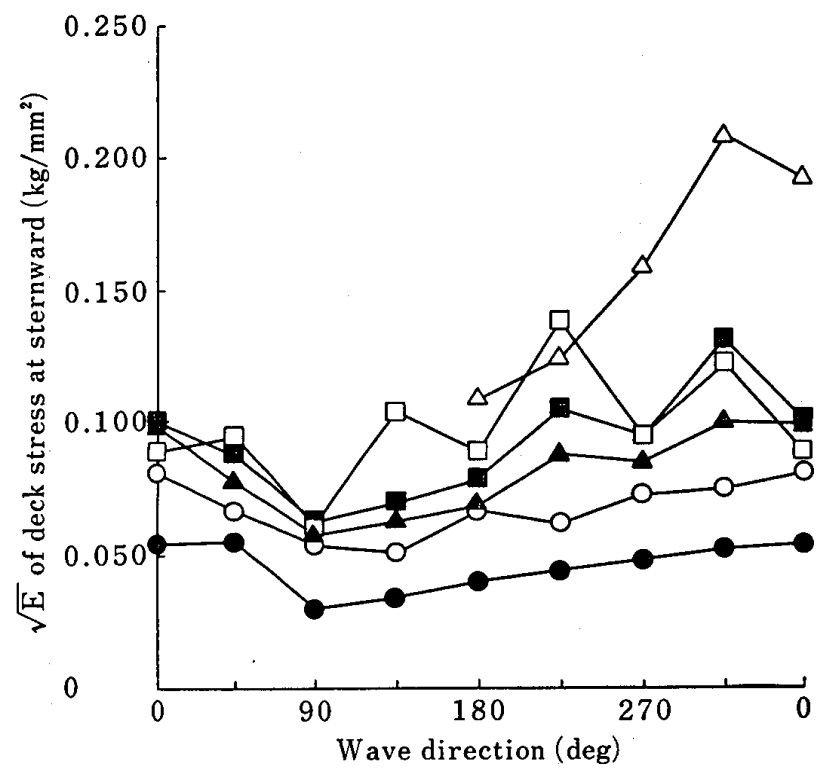

(c) 船尾部甲板紛曲げ応力

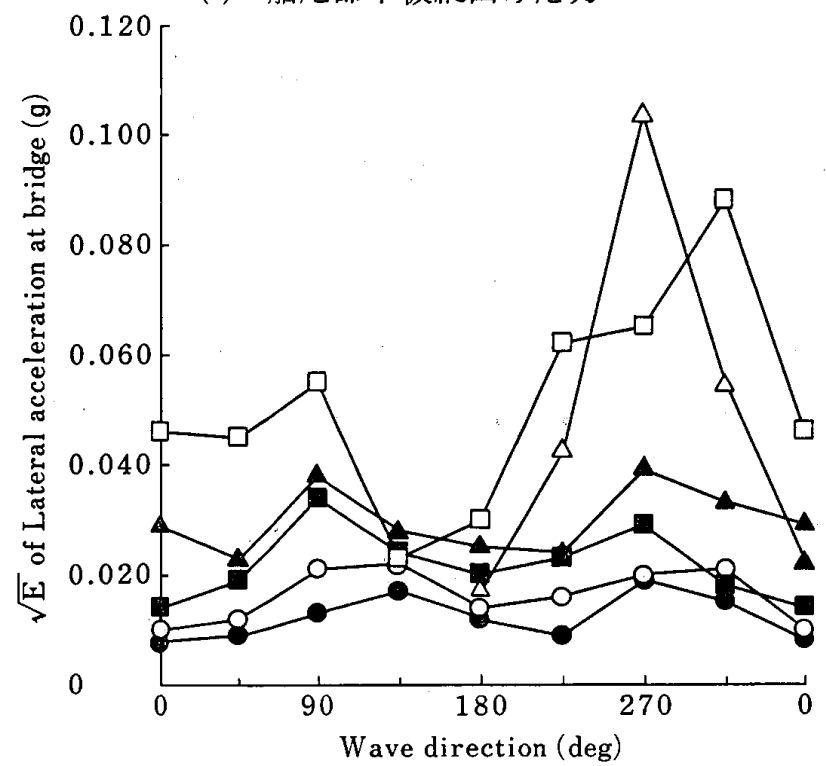

(e) 船橋水平加速度

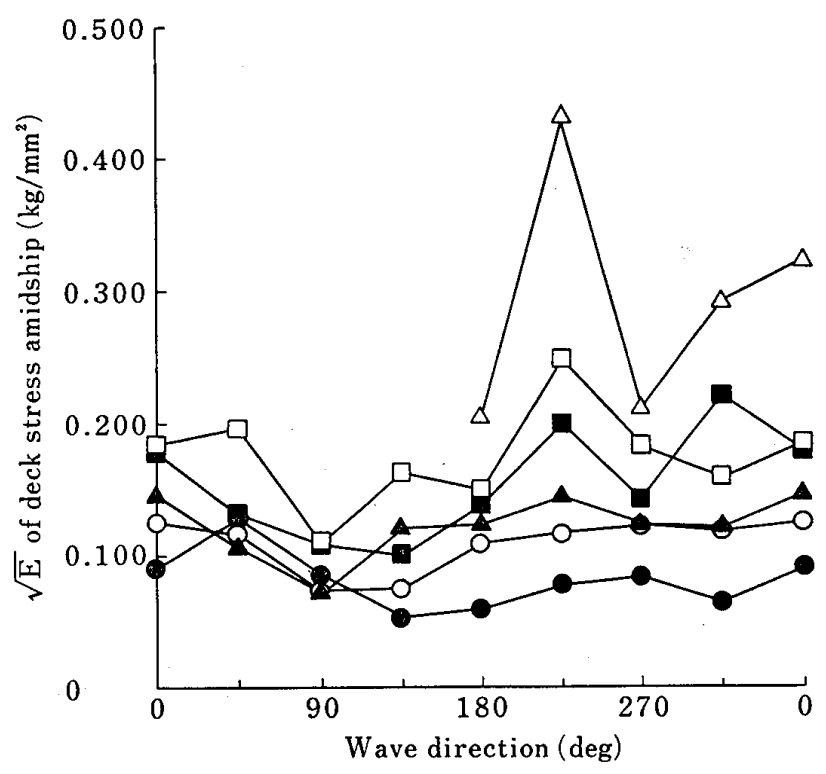

(b) 中央部甲板綎曲げ応力

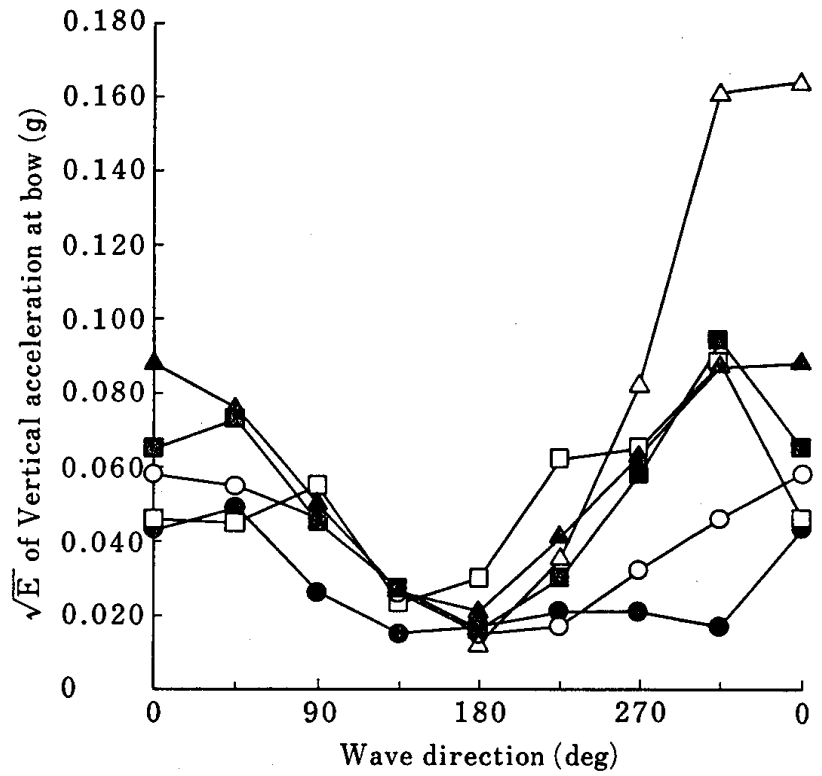

(d) 船首垂直加速度

図 7 船体応答と波の出会い角度との関係

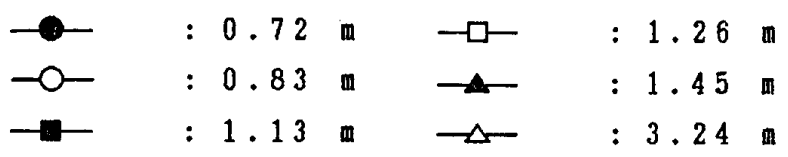


置されていることに起因していることも考光られ る。したがって応力センサは両舫の対称な位置に 設置することが望ましいと考光る。

図 7 (d) 飞示すように船体のピッチング運動に対 応する船首部垂直加速度は，向かい波を受けて航 走する状態ほどその変動が大きく，追い波を受け て航走する状態添ど変動が小さくなることが顕著 である。また船体のローリング運動に対応する船 橋の水平加速度については, 図7 (e) に示すよう に，船体正横から波を受けて航走する状態でその 変動は大きくなっている。

図 7 (a)〜 (e) 亿よれば各船体応答とも波高の大き さにより，その変動が大きくなる傾向が認められ る。波高と各船体応答との相関係数を求め各船体 応答諸量と波高との関係を調べた（表 4)。その 結果, 波高と各船体応答との間に強い相関が認め られ，また各船体応答間にも波の出会い角度每に 高い相関をもつ組合わせが認められる。したがっ て, 波の出会い角度を把握し任意の船体応答を計 测することにより，他の応答を推定評価すること が可能と考兄られる。ただし，推定式を構筑する にはさらに継続的な計測によるデータの蓄積が必 要と考学る。

各船体応答データについてスペクトラム解析を 行ない, パワースペクトラムの卓越するピーク周
衰 4 波高扣よび船体応答の相関行列

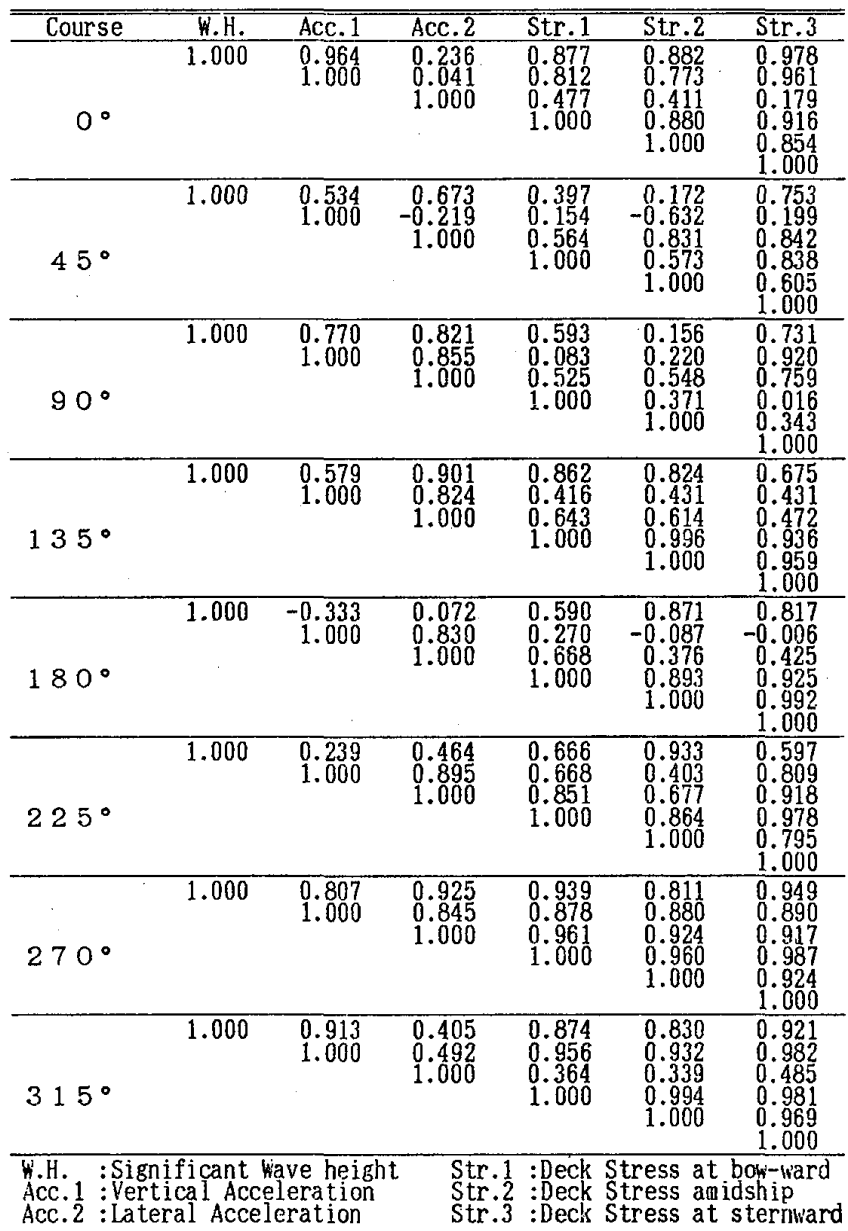

期と波高特よび波の出会い角度との関係を示したものが図 $8(\mathrm{a})$ ( $\mathrm{e})$ である。各図とも縱軸に周波数を，横軸に波 の出会い角度をとっている。

図 8 (a)〜(c) K示すように，船体縦曲げ応力の変動の周波数特性には波の出会い角度の影響が顕著に現われてい る。即ち，追い波を受けて航走する状態になるほどその変動周期は長くなり，その值は向かい波を受けて航走す る状態の約 4〜 7 倍に達している。これは，波との出会い周期の相違が現われたものと考える。

図 8 (d) 亿船首垂直加速度の変動の周波数特性を示すが，波高扤よび波の出会い角度の違いによる影響はあまり 認められず，その值は $0.2 \pm 0.03 \mathrm{~Hz}$ の範团である。しかしながら，有義波高で $3.24 \mathrm{~m}$ の状態では，波を斜め後 方に受けて航走した場合拉よび船尾方向より波を受けて航走した場合の周波数特性がそれぞれ，0.088Hz，0.064 $\mathrm{Hz}$ と極端に低く, ピッチング運動の周期が長くなっていることが認められた。波高の度合によってピッチング 運動の周期にどのような変化が生じるのかという問題についても，今後さらにデータの蓄積が必要と考学る。

船橋の水平加速度の变動の周波数特性を図 $8(\mathrm{e})$ に示すが，波高特よび波の出会い角度の違いによる影響はあま り認められず，0.11士0.01 Hz と船首垂直加速度に比較して更に周期変動が小さい。このことは，実験を実施し た海況の範囲では船体の横動摇周期がほぼ一定なことを示している。な特, 垂直加速度ならびに水平加速度の計 測値には上下動，左右動の影響が含まれているものと考えられるが，これらについては今後更に多くの計測処理 による検討が必要である。

結言

静水状態に於ける甲板縦㐫力の計測並びに計算值との比较い検討を行なうとともに航行中の船体応答について 実船計測実験を実施した。その結果を要約すると以下の通りである。

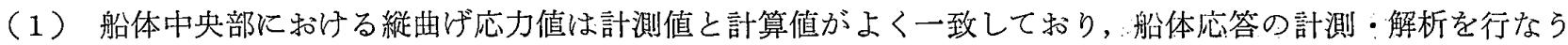




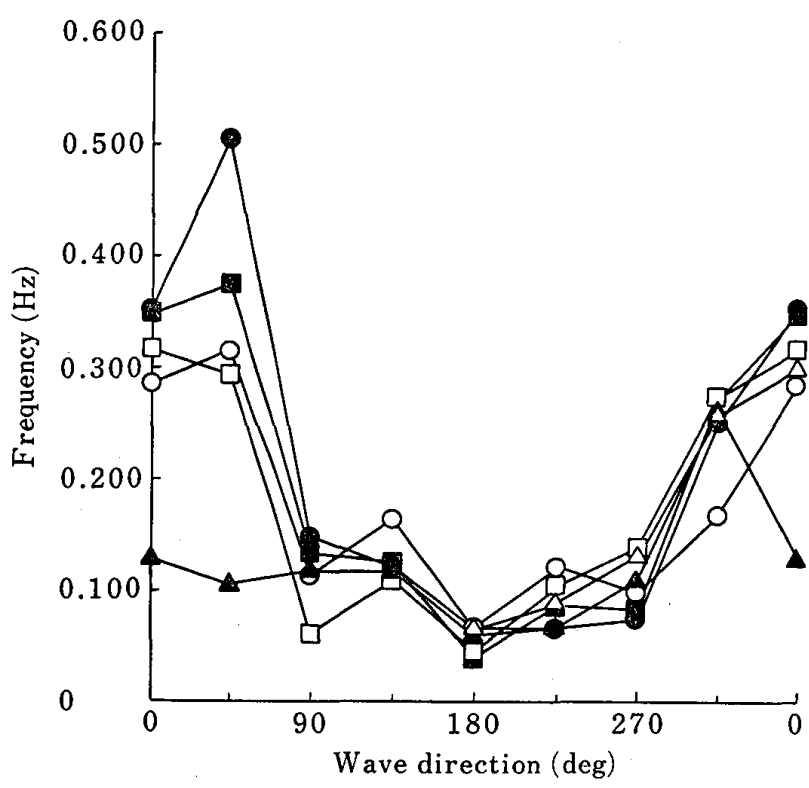

(a) 船首部甲板縦曲げ応力

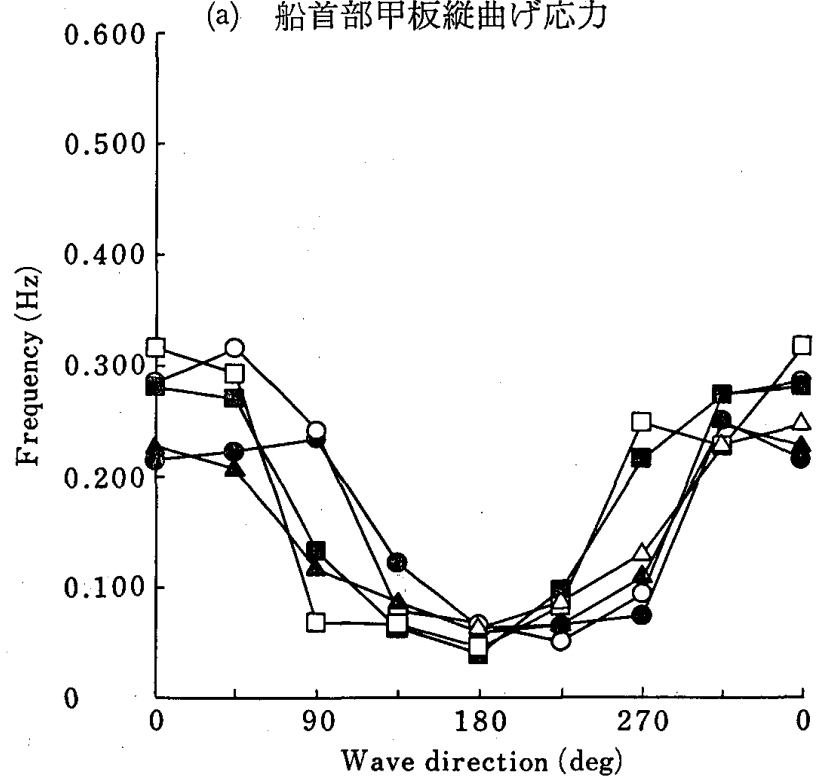

(c) 船尾部甲板縦曲げ応力

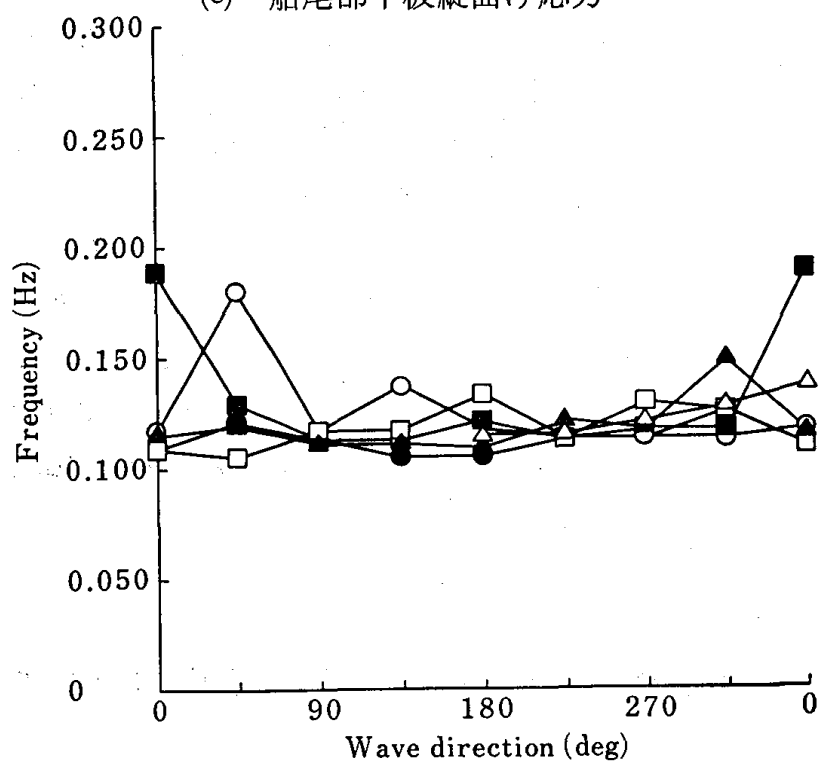

(e) 船橋水平加速度

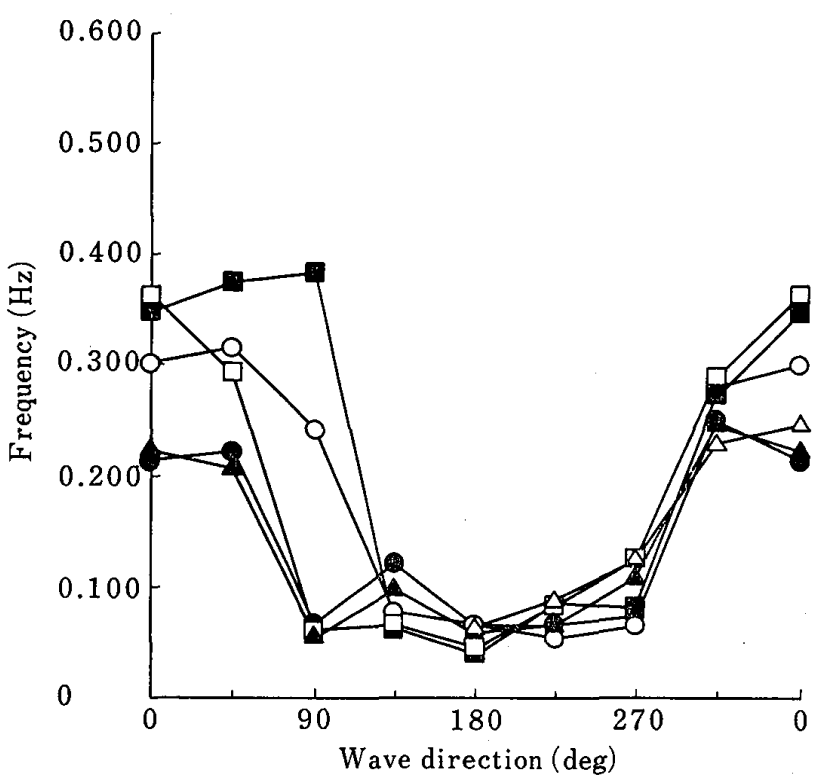

(b) 中央部甲板縦曲证応力

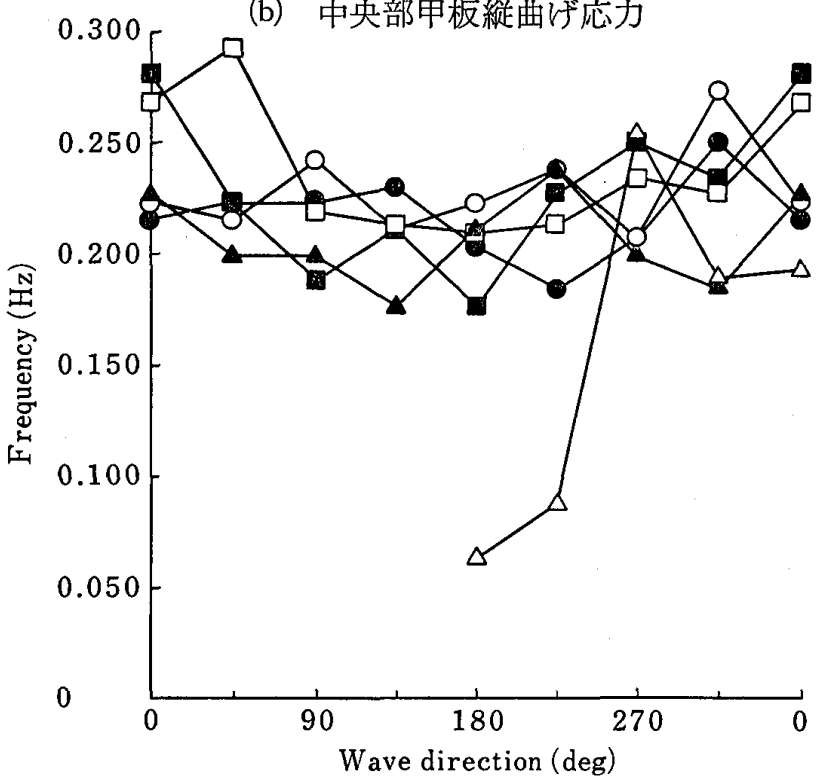

(d) 船首垂直加速度

図 8 船体応答の周波数特性と波の出会い角度との関係

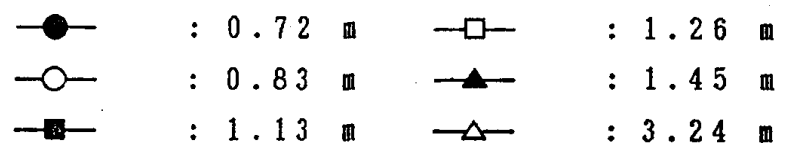


上で一つの基準とすることができた。

（2）船体船首部で計測している縦曲げ応力には, 設置籄所の関係から気温の影響が強く現われているので, 航 行中及び操業中の計測時にはその影響を充分に洘慮する必要がある。

（3）船体応答データの頻度分布から, 神鷹丸は船体縱強度が大きいことが確認され, 実験を実施した海況の範

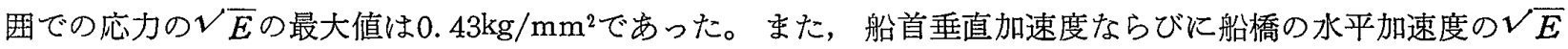
の最大值はともに $0.164 \mathrm{~g}$ であった。

（4）船体縦曲げ応力の変動レベルは，右舷側に波を受けて航走している状態での变動レベルが左舫側のそれよ りも高く，特に右輆斜め後方から波を受けて航走する状態で高い。

（5）船首部垂直加速度は向い波の状熊に近づくほどその応答レベルは大きくなる。一方船橋の水平加速度は， 横波を受ける状態に近づくほど芯答レベルが大きくなる。

（6）航行中に括ける船体応答諸量は, 波との出会い角度をパラメータとしたときに, 波高との間に強い相関が 認められた。また各船体応答間においても同様の関係を認めることができた。したがって任意の船体応答を計 測することにより他の船体応答の推定評価をする可能性が示唆された。

（7）船橋の水平加速度の周波数特性を解析することにより, 神鷹丸の横動摇周期は, 実験を実施した海況の範 囲では波高和よび波との出会い角度に係わらず一定である。

\section{参 考 文 献}

（1）山本政治・平川雄二・山口賢二：航海情報システム (CANCY-II) 飞ついて, 日本造船学会誌, 第701号, pp. 767-771, 1987

（2）菅井和夫・湯浅通史：船体強度モニタリングシステムについて，日本造船学会誌，第705号，pp. 153-176， 1988

（3）染矢隆一・岡田裕・有川彰一・仁藤雅夫・八木光・国武吉邦：波浪中に和ける操船判断に関する実証的研究 一その 1 船体運動状態表示の開発一，日本造船学会論文集，第161号，119-127，1987

（4）秋田好雄，船体縱強度に関するトータルシステム，日本造船学会論文集，第135号，pp. 229-238，1976

（5）湯浅通史・鈴木康平・多田羅豊：船体強度モニタリングシステムの実船試験，日本海事協会会誌，第190号， pp. $88-98,1985$

(6) 湯浅通史・鈴木康平・多田羅豊: 実船の就航時の船体応答について(第 1 報 自動車運搬船の船体応答), 日 本造船学会論文集, 第159号, pp. 217-228, 1986

（7）湯浅通史・河地三郎・鈴木康平・多田羅豊：実船の就航時の船体応答について（第 2 報 大型ばら積貨物船 の船体応答)，日本造船学会論文集，第161号，pp. 293-303，1987

（8）湯浅通史・鈴木康平・多田羅豊：実船の就航時の船体応答について（第 3 報 船体応答の監視），日本造船 学会論文集), 第163号, pp. 314-321，1988

（9）高橋幸伯・小畑和彦・能勢義昭・杉田洋一：コンテナ船の長期実船計測（第 1 報）, 日本造船学会論文集, 第150号, pp. 327-332, 1981

(10) 高橋幸伯・小畑和彦・能勢義昭・杉田洋一：コンテナ船の長期実船計測 (第 2 報), 日本造船学会論文集, 第152号，pp. 268-274，1981

(11) 西ノ首英之・川島利兵衛：実船試験による漁船の耐航性について一III, 日本航海学会論文集, 第 55 号, pp. $1-6,1976$

(12) 西ノ首英之・川島利兵衛 : 実船試験による㵂船の耐航性についてーN, 日本航海学会論文集, 第56号, pp. $77-89,1976$

(13) 西ノ首英之・川島利兵衛：実船試験による漁船の耐航性についてーV, 日本航海:学会諭文集, 第56号, pp. $91-100,1976$

(14) 西ノ首英之・川囟利兵衛：実船試験による漁船の耐航性についてーVI, 日本航海学会論文集, 第57号, pp. 101-105, 1977

(15) 井上清・武田誠一・今関昭博・宮崎芳夫・佐藤要・山口雄三：東京水産大学神鷹丸船体応答解析システム, 
日本航海学会誌，第94号，49-53，1987

(16) 武田誠一・佐藤要・井上清・宮崎芳夫 : 船体応力計測システムの静的性能について, 東京水産大学研究報告, 第75巻 2 号, pp. $361-374,1988$

(17) 武田誠一・佐藤要・井上清・宮崎芳夫 : 神鷹丸の航行中の船体応答について, 東京水産大学研究報告, 第77 巻 1 号, pp. 83-93, 1990

(18) 住友重機械工業(㛦)：東京水産大学練習船神鷹丸軽荷重量重心計算書等，1984

(19) 住友重機械工業(㑣)：東京水産大学練習船神蔦丸構造部材計算書等, 1984

\section{質 疑 応 答}

桑島 進 (東京商船大学) : 有義波高最大 $(3.24 \mathrm{~m})$ の時の神鷹丸の最大ローリング角, ピッチング角はどの程 度であったのか技教え下さい。

武田誠一：船首より波を受けて航走している時に最大ピッチング角が計測され7.3（船首上向き）～7.5度（船首 下向き)です。最大ローリング角は右艆正横に波を受けて航走している時に計測され，17.0 (右傾斜) 23.0 度 (左傾斜) でした。 